ISSN: 1410-8917

Jurnal Kimia

- Sains \&

Aplikasi

e-ISSN: 2597-9914
Jurnal Kimia Sains dan Aplikasi 21 (3) (2018): 107 - 112

\section{Jurnal Kimia Sains dan Aplikasi Journal of Scientific and Applied Chemistry}

Journal homepage: http://ejournal.undip.ac.id/index.php/ksa

\title{
Comparative Test of Color Stability between Betalain Pigments of Red Dragon Fruits and Anthocyanin Pigments from Tamarillo Fruit at Various $\mathrm{pH}$
}

\author{
Yelfira Sari ${ }^{a^{*}}$, Adlis Santoni ${ }^{b}$, Elisabet ${ }^{b}$ \\ a Universitas Islam Riau, Jl. Kaharuddin Nasution No. 113, Pekanbaru, Riau, Indonesia \\ b Universitas Andalas, Padang, Indonesia \\ * Corresponding author: yelfirasari@edu.uir.ac.id \\ https://doi.org/10.14710/jksa.21.3.107-112
}

\section{Article Info \\ Article history: \\ Received: 15 May 2018 \\ Revised: 16 July 2018 \\ Accepted: 16 July 2018 \\ Online: 26 July 2018}

Keywords:

betalain, betacyanin, anthocyanin, dragon fruit, tamarillo

Kata Kunci:

betalain, betasianin, antosianin, buah naga merah, terung belanda

\section{Abstract}

Betalains and anthocyanins are classes of natural and water soluble pigments. Now days, these pigments have been developed as a replacement colouring agents. One of betalain resource is dragon fruit and anthocyanin resource is tamarillo. These pigments are relative unstable in some condition, one of them is $\mathrm{pH}$. This research aim is to determine stability of betalain and anthocyanin pigments by $\mathrm{pH}$ parameter. These pigments can be isolated by macerated methods, technically processed by chopping the fruit and than soaking in ethanol for $\pm 24 \mathrm{~h}$. These extracts were condensed by rotary evaporator. These extracts were analysed by ultraviolet-visible spectrophotometer at wavelength $(\lambda)$ 200$800 \mathrm{~nm}$. The absorption spectrum showed two major absorption peaks at $269 \mathrm{~nm}$ and $536 \mathrm{~nm}$ for betalain and $531 \mathrm{~nm}$ for anthocyanins. The result showed the optimal $\mathrm{pH}$ for betalain stability was at $\mathrm{pH} 5$ and $\mathrm{pH} 3$ for anthocyanin

Abstrak

Pigmen betalain dan antosianin merupakan pigmen alami yang larut dalam air. Dewasa ini, penggunaan pigmen-pigmen tersebut telah banyak dikembangkan untuk menggantikan pewarna sintetik yang berbahaya bagi kesehatan manusia. Salah satu penghasil pigmen betalain adalah buah naga merah, sementara penghasil antosianin adalah terung belanda. Pigmen-pigmen ini relatif tidak stabil terhadap beberapa faktor, salah satunya adalah $\mathrm{pH}$. Penelitian ini bertujuan untuk menentukan kestabilan dari pigmen betalain dan pigmen antosianin berdasarkan parameter $\mathrm{pH}$. Pigmen tersebut dapat diisolasi dengan metoda maserasi, yang secara teknis dapat dilakukan dengan memotong serat buah sumber pigmen kemudian merendam buah tersebut di dalam etanol selama \pm 24 jam dan dilanjutkan pemekatan menggunakan vakum penguap. Ekstrak etanol yang diperoleh dianalisis menggunakan spektrofotometer ultravioletvisible (UV-Vis) pada panjang gelombang ( $\lambda$ ) 200-800 nm. Dari ekstrak buah naga merah didapatkan dua puncak absorban, yaitu pada $\lambda 269 \mathrm{~nm}$ dan $536 \mathrm{~nm}$ sedangkan dari ekstrak terung belanda didapatkan puncak absorban pada $\lambda 531 \mathrm{~nm}$. Hasil penelitian menunjukkan bahwa struktur molekul pigmen betalain stabil pada $\mathrm{pH}$, sementara struktur molekul pigmen antosianin stabil pada $\mathrm{pH} 3$. 


\section{Pendahuluan}

Betalain dan antosianin merupakan pigmen alami yang terdapat di dalam tumbuh-tumbuhan. Pigmenpigmen ini larut di dalam air [1, 2] sehingga bisa diekstraksi dengan alkohol [3]. Betalain merupakan pigmen yang mengandung atom nitrogen dan terdiri dari campuran betasantin kuning dan betasianin merah [4] dan merupakan salah satu pewarna alami yang banyak digunakan di industri makanan [5] serta termasuk pewarna alami yang pertama dikembangkan [6]. Antosianin merupakan pigmen yang termasuk ke dalam kelompok flavonoid dari senyawa polifenol [7, 8]. Selain digunakan sebagai pewarna makanan, antosianin juga memiliki banyak manfaat bagi kesehatan manusia seperti mengurangi resiko penyakit kanker, jantung, diabetes, dan obesitas [9-11].

Pigmen betalain dan antosianin memiliki kesamaan warna dalam spektrum sinar tampak [12]. Namun demikian, kedua pigmen ini memiliki beberapa perbedaan pada struktur kimianya, seperti yang ditampilkan pada Gambar $1[4,13]$. Terlihat pada Gambar 1, pigmen betalain memiliki ikatan nitrogen, sedangkan pigmen antosianin tidak memiliki ikatan nitrogen. Jika suatu tanaman mengandung betalain, maka tanaman tersebut tidak akan menghasilkan antosianin. Hal ini disebabkan karena pada tanaman yang menghasilkan betalain kekurangan enzim antosianidin sintase yang berperan dalam tahapan akhir pada jalur biosintesis antosianin [14].

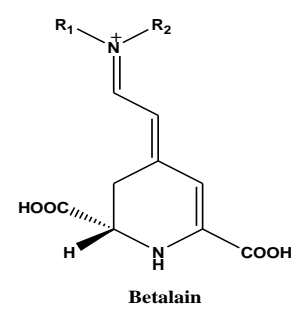

(a)

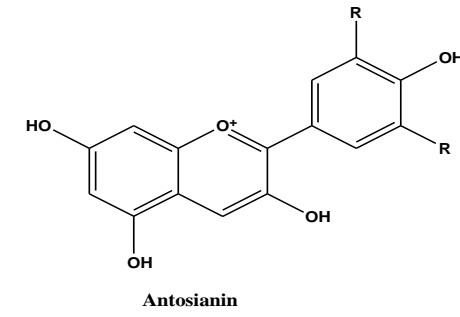

(b)
Gambar 1. Struktur molekul (a) pigmen betalain dan (b) pigmen antosianin

Betalain mempunyai dua subklas yaitu betasianin dan betasantin. Betasianin menunjukkan kandungan pigmen merah-ungu dan terbentuk dari hasil kondensasi dari asam betalamat dengan siklo-DOPA sedangkan betasantin menunjukkan pigmen kuning-jingga dan terbentuk dari konjugasi antara asam betalamat dengan amina atau dengan asam amino [15].

Antosianin merupakan glikosida dari turunan polihidroksi dan polimetoksi dari kation 2fenilbenzopirilium atau kation flavilium [8]. Baik pigmen betalain maupun antosianin relatif tidak stabil terhadap beberapa faktor, diantaranya terhadap panas, $\mathrm{pH}$, cahaya, dan oksigen $[16,17]$

Moldovan dan David [7] pada tahun 2014 telah melakukan penelitian mengenai kestabilan pigmen antosianin terhadap temperatur, dimana sampel diberikan perlakuan pada tiga temperatur yang berbeda, yaitu pada temperatur $2^{\circ} \mathrm{C}, 25^{\circ} \mathrm{C}$, dan $75^{\circ} \mathrm{C}$. Dari hasil penelitian ini didapatkan bahwa pada suhu $75^{\circ} \mathrm{C}$, pigmen antosianin mengalami degradasi terbesar dengan kecepatan rata-rata $82,76 \times 10^{-3} / \mathrm{h}$.

Woo $d k k$. [16]. pada tahun 2011 juga telah melakukan penelitian mengenai kestabilan pigmen betalain terhadap temperatur. Sampel yang digunakan adalah buah naga merah, dimana sampel diberi tiga perlakuan temperatur yang berbeda, yaitu pada temperatur $25^{\circ} \mathrm{C}$, $50^{\circ} \mathrm{C}$, dan $85^{\circ} \mathrm{C}$. Dari hasil penelitian diketahui bahwa sampel mengalami degradasi warna hingga 30\% di awal penyimpanan pada temperatur $80^{\circ} \mathrm{C}$.

Dari dua penelitian di atas, dapat disimpulkan bahwa baik pigmen antosianin maupun pigmen betalain tidak stabil pada temperatur yang tinggi. Pigmen-pigmen ini akan mengalami degradasi warna setelah melalui proses pemanasan. Selain terhadap pemanasan, pigmenpigmen ini juga tidak stabil pada $\mathrm{pH}$ yang bersifat basa. Oleh karena itu perlu dilakukan penelitian untuk mengetahui pada $\mathrm{pH}$ berapa pigmen antosianin dan pigmen betalain memiliki degradasi warna paling kecil.

\section{Metode Penelitian}

\subsection{Alat dan Bahan}

Alat: Seperangkat alat distilasi, seperangkat alat vakum penguap (rotary evaporator, Buchi, Swetzerland), spektrofotometer UV/Vis (UV-1700 series Shimadzu, Jepang), pH meter (Eutech $\mathrm{pH} 5^{+}$), kertas saring, alumunium foil, serta peralatan gelas yang umum digunakan dalam laboratorium.

Bahan: Daging buah naga merah, daging buah terung belanda, etanol $96 \%$ (teknis), $\mathrm{HCl}$ (p.a, Merck), asam asetat glasial (p.a, Merck), ammonium asetat (p.a, Merck), amonia (p.a, Merck), ammonium klorida (p.a, Merck), asam sitrat (teknis), dinatrium hidrogen pospat, dan akuades.

\subsection{Ekstraksi dan analisis betalain}

Ekstraksi betalain dari buah naga merah maupun antosianin dari terung belanda yang diperoleh dari Padang, Sumatera Barat dapat dilakukan sebagai berikut, daging buah naga merah dan terung belanda sebanyak 100 gram dipotong dadu kecil $(1 \mathrm{x} 1 \mathrm{~cm})$ kemudian masing-masing dihomogenkan dengan $200 \mathrm{~mL}$ etanol. Bubur buah yang diperoleh dimaserasi selama \pm 24 jam, setelah itu disaring dengan kain kasa dan dilanjutkan dengan penyaringan vakum. Filtrat yang diperoleh diuapkan dengan vakum (rotary evaporator, Buchi, Swetzerland) hingga didapatkan ekstrak buah. Ekstrak buah ini kemudian dianalisis lebih lanjut menggunakan spektrofotometer UV-Vis pada panjang gelombang 200$800 \mathrm{~nm}$. 
2.3 Uji kestabilan struktur molekul terhadap perubahan pH larutan

Ekstrak buah sebanyak $10 \mathrm{~mL}$ dilarutkan ke dalam larutan buffer $\mathrm{pH} 1,3,5,7$, dan 9 hingga volume mencapai $50 \mathrm{~mL}$. Masing-masing larutan kemudian diukur absorbansinya terhadap sinar ultraviolet-visible (UV-vis) menggunakan spektrofotrometer UV-Vis pada panjang gelombang 200-800 $\mathrm{nm}$.

\section{Hasil dan Pembahasan}

\subsection{Analisis absorbansi UV-Vis}

Analisis absorbansi UV-Vis ekstrak buah naga merah memberikan hasil dua puncak absrorbansi maksimum pada panjang gelombang $269 \mathrm{~nm}$ dan $536 \mathrm{~nm}$ seperti yang ditunjukkan pada Gambar 2. Panjang gelombang 269 dan $536 \mathrm{~nm}$ ini merupakan panjang gelombang karakteristik untuk betalain merah-ungu atau disebut juga dengan betasianin [15].

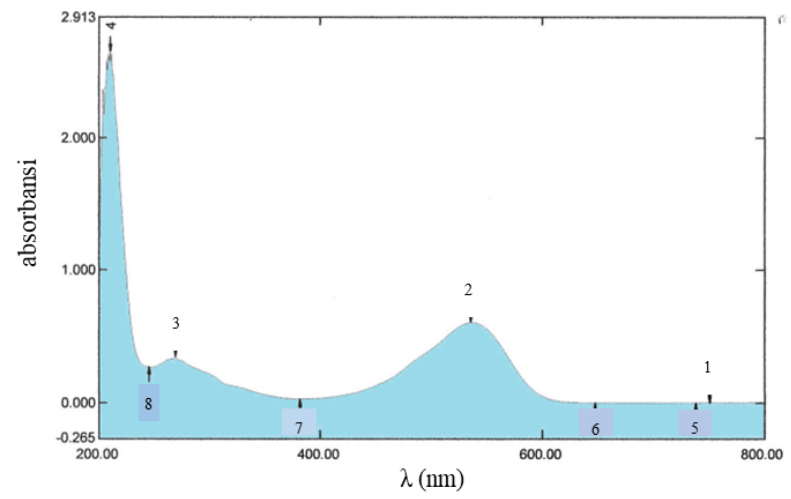

Gambar 2. Spektrum UV-Vis pigmen betalain pada kondisi awal ( $\mathrm{pH}$ 5)

Azeredo [15] menyebutkan bahwa betalain terdiri dari dua subklas yaitu betasianin dan betasantin. Betasianin merupakan subklas betalain yang memiliki warna merah-ungu dan memiliki absorbansi maksimum pada panjang gelombang 270-280 nm untuk daerah sinar ultraviolet dan panjang gelombang 535-540 nm untuk daerah sinar tampak. Sedangkan betasantin merupakan subklas betalain yang memiliki warna kuning-jingga dan memberikan absorbansi maksimum pada panjang gelombang 470-486 nm. Jadi, berdasarkan hasil yang diperoleh dari Gambar 2 dapat disimpulkan bahwa pigmen yang terkandung di dalam buah naga merah adalah pigmen betalain berupa senyawa betasianin.

Di pihak lain, ekstrak buah terung belanda memberikan hasil absorbansi maksimum pada panjang gelombang $534 \mathrm{~nm}$ seperti yang terlihat pada Gambar 3. Menurut Giusti dan Wrolstad [18], senyawa antosianin mempunyai panjang gelombang spesifik pada 490-550 nm pada daerah sinar tampak, sehingga dapat disimpulkan bahwa pigmen yang terkandung dalam buah terung belanda ini adalah pigmen antosianin jenis peonidin-3-galaktosida.

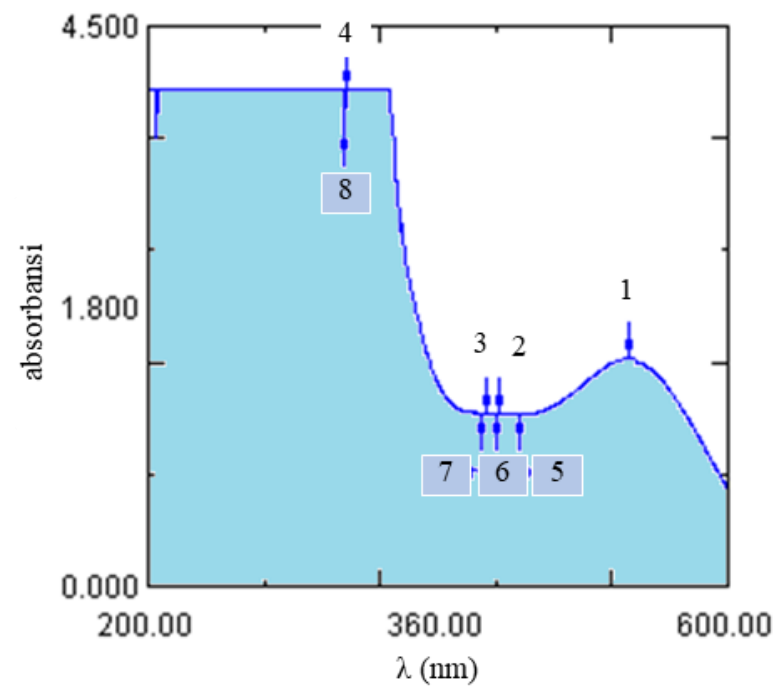

Gambar 3. Spektrum UV-Vis pigmen antosianin pada kondisi awal ( $\mathrm{pH} 3$ )

\subsection{Uji kestabilan struktur molekul terhadap perubahan pH larutan}

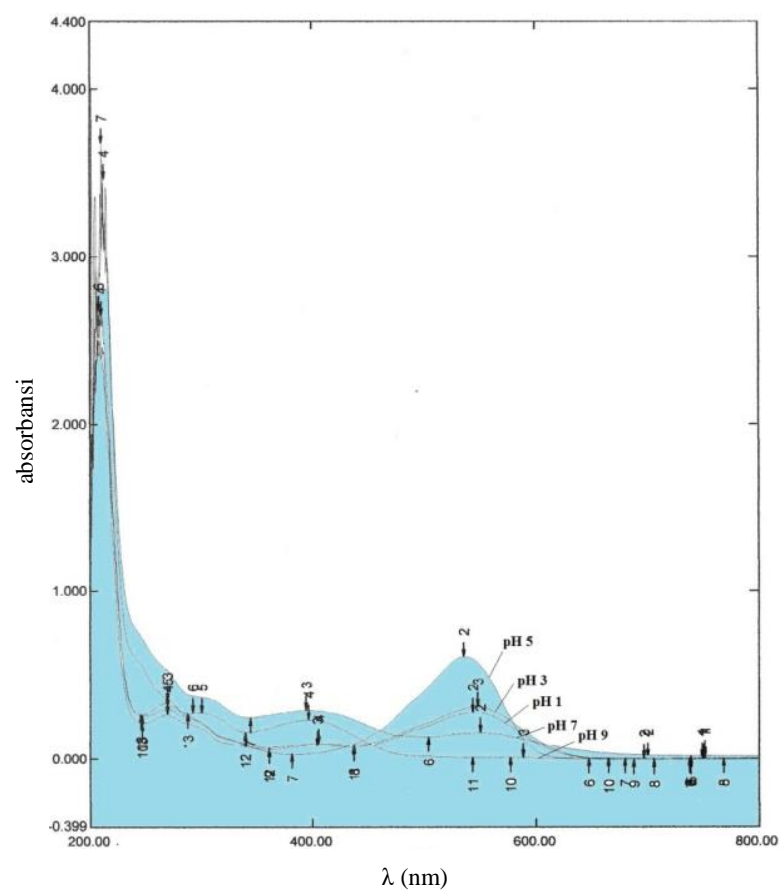

Gambar 4. Spektrum UV-Vis pigmen betalain berbagai variasi $\mathrm{pH}$

Spektrum UV-Vis pigmen betalain pada berbagai variasi $\mathrm{pH}$ (Gambar 4) menunjukkan bahwa pada $\mathrm{pH} 1$ dan $\mathrm{pH} 3$ terjadi pergeseran absorbansi pada panjang gelombang maksimum pada daerah tampak dari $536 \mathrm{~nm}$ menjadi $548 \mathrm{~nm}$ untuk pH 1 dan $544 \mathrm{~nm}$ untuk pH 3. Di sisi lain, pada $\mathrm{pH} 5$ tidak terjadi pergeseran panjang gelombang maksimum. Sedangkan pada $\mathrm{pH} 7$ dan $\mathrm{pH} 9$ tidak tampak adanya puncak betalain. Hal ini menunjukkan bahwa pigmen betalain stabil pada $\mathrm{pH} 5$ dan mengalami kerusakan pada $\mathrm{pH} 7$ dan $\mathrm{pH} 9$. Sedangkan pada $\mathrm{pH} 1$ dan $\mathrm{pH}$ 3, pigmen betalain tersebut tidak terlalu stabil. 
Selanjutnya, spektrum UV-Vis antosianin pada berbagai variasi nilai $\mathrm{pH}$ ditunjukkan pada Gambar 5 .

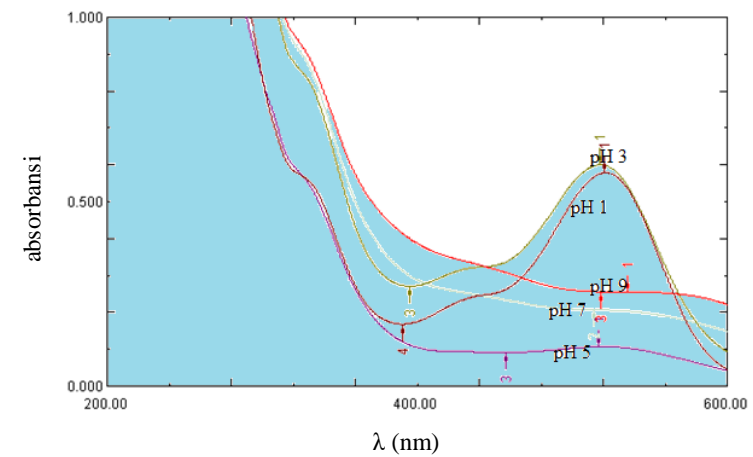

Gambar 5. Spektrum UV-Vis pigmen antosianin pada berbagai variasi $\mathrm{pH}$

Terlihat pada Gambar 5 bahwa absorbansi UV-Vis antosianin pada $\mathrm{pH} 3$ lebih besar dibanding pada $\mathrm{pH} 5$ (6: 1) meskipun terletak pada panjang gelombang yang sama, yaitu $517 \mathrm{~nm}$. Hal ini dapat dilihat dari nilai absorban antosianin pada $\mathrm{pH} 3$ yaitu sebesar 0,600 sedangkan absorban antosianin pada $\mathrm{pH} 5$ hanya sebesar 0,100. Absorbansi UV-Vis antosianin pada pH 7 dan $\mathrm{pH} 9$ mengalami pergeseran pada panjang gelombang 270,5 nm untuk pH 7 dan 535,5 nm untuk pH 9.

Struktur molekul pigmen betalain relatif lebih stabil terhadap $\mathrm{pH}$ dibandingkan dengan antosianin. Hal ini ditunjukkan oleh range $\mathrm{pH}$ untuk betalain yang lebar yaitu antara 3 hingga 7, struktur molekul betalain tidak berubah [15]. Sementara itu, struktur molekul antosianin tidak berubah pada $\mathrm{pH}$ kurang dari 4 .

\subsection{Perubahan warna pigmen betalain dan} antosianin pada berbagai variasi nilai $\mathrm{pH}$ dan hubungannya dengan perubahan struktur molekulnya
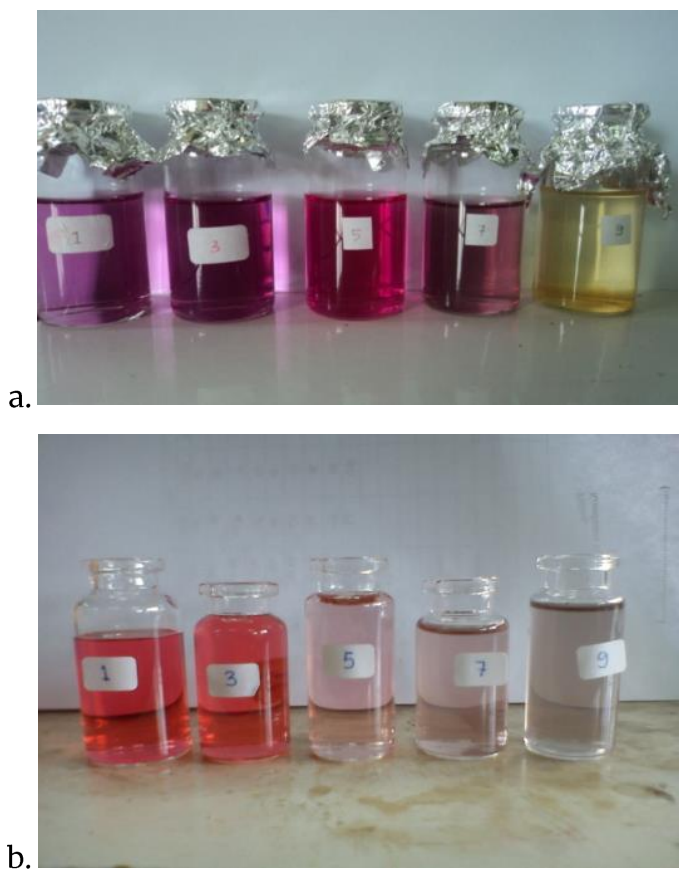

Gambar 6. Perubahan warna (a) pigmen betalain dan (b) pigmen antosianin pada berbagai variasi nilai $\mathrm{pH}$
Perubahan warna pigmen betalain dan antosianin pada berbagai variasi nilai $\mathrm{pH}$ dapat dilihat pada Gambar 6. Terlihat pada Gambar 6a bahwa warna ekstrak buah naga pada $\mathrm{pH} 5$ hampir tidak berubah dari warna awal sedangkan pada $\mathrm{pH} 7$ dan $\mathrm{pH} 9$ terjadi perubahan warna yang sangat jelas, dimana semakin basa larutan tersebut, maka warnanya berubah menjadi kuning. Sedangkan pada $\mathrm{pH} 3$ dan $\mathrm{pH}$ 5, warna larutan hampir tidak berubah dari warna awal (warna larutan tanpa pengaturan $\mathrm{pH}$ ). Sementara itu pada Gambar 6b terlihat bahwa untuk pigmen antosianin, semakin asam $\mathrm{pH}$ suatu larutan maka warna yang dihasilkan pigmen ini semakin cerah. Sebaliknya semakin basa larutan, maka warna yang ditimbulkan semakin pucat/tak bewarna. Pada $\mathrm{pH} 1$ dan $\mathrm{pH}$ 3, larutan berwarna merah cerah sedangkan pada $\mathrm{pH}$ 5 dan pH 7 warna larutan berubah menjadi lembayung dan pada akhirnya menjadi tidak berwarna (bening) pada $\mathrm{pH} 9$.

Menurut Azeredo [15], perubahan warna pigmen betalain yang terjadi pada $\mathrm{pH} 7$ dan 9 disebabkan oleh hidrolisis ikatan aldimin, dimana akan menyebabkan terjadinya pengurangan warna merah menjadi merah pucat ataupun berubah menjadi kuning terang, yang menghasilkan senyawa tidak berwarna siklo-DOPA-5O- $\beta$-glukosida dan asam betalamat berwarna kuning cerah. Rekasi pemutusan ikatan ini dapat dilihat pada Gambar 7.

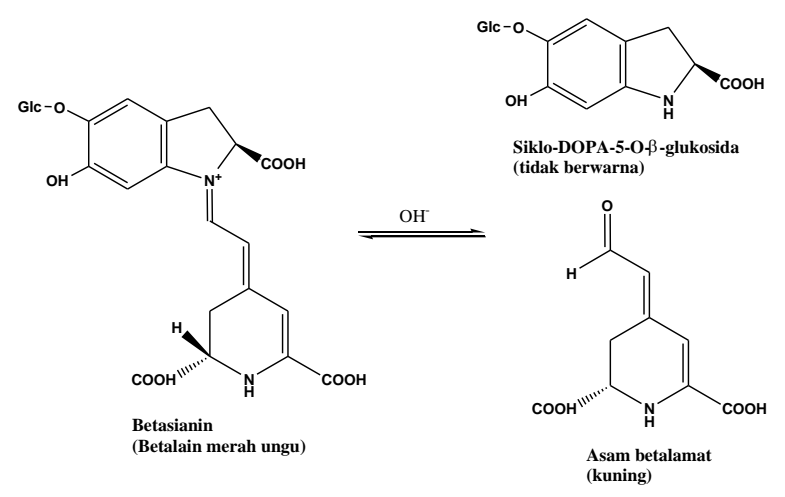

Gambar 7. Reaksi pemutusan ikatan senyawa betasianin pada $\mathrm{pH}>7$ [15]

Sedangkan pada kondisi asam terjadi reaksi isomerisasi sehingga menghasilkan senyawa isobetanin seperti yang ditampilkan pada Gambar 8 .

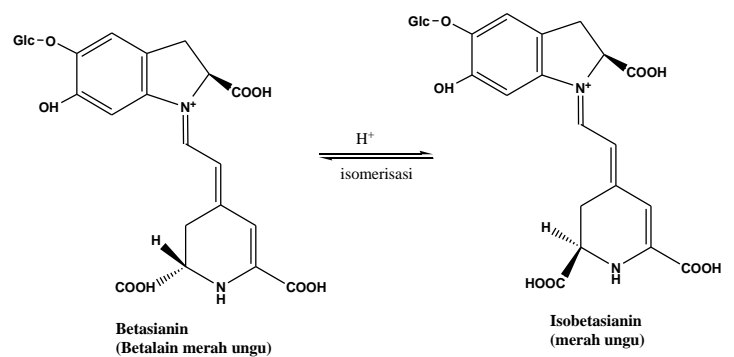

Gambar 8. Reaksi isomerisasi senyawa betasianin pada $\mathrm{pH}<3[15]$ 
Sedangkan untuk perubahan warna pigmen antosianin, menurut Giusti dan Wrolstad [18], terjadi karena pada $\mathrm{pH}$ yang berbeda struktur molekul antosianin mengalami perubahan menjadi basa quinonoidol berwarna biru pada $\mathrm{pH} 7$ dan kation flavilium berwarna orange-ungu pada $\mathrm{pH}$ 1, seperti yang terlihat pada Gambar 9.

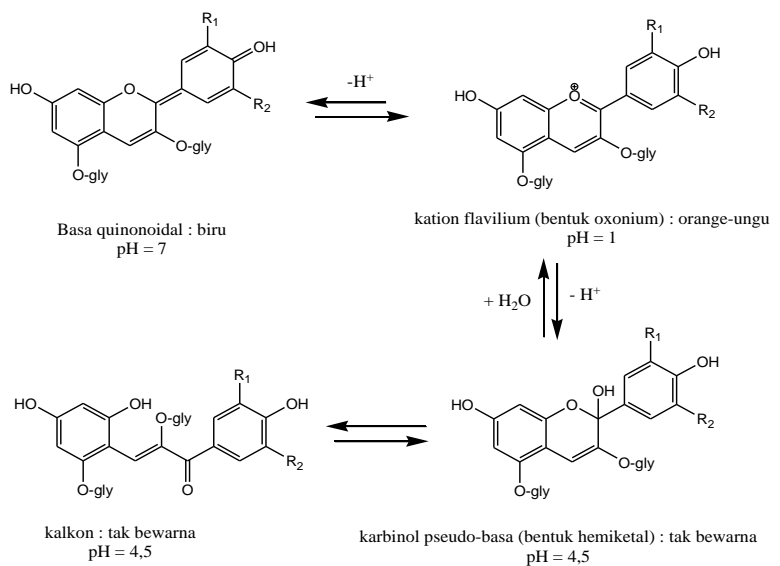

Gambar 9. Perubahan struktur antosianin pada $\mathrm{pH}$ yang berbeda [18]

\section{Kesimpulan}

Warna maupun strukur molekul pigmen betalain relatif lebih stabil terhadap perubahan nilai $\mathrm{pH}$ larutan dibandingkan dengan antosianin. Secara spesifik, warna maupun struktur molekul pigmen betalain lebih stabil pada $\mathrm{pH} 5$ sedangkan antosianin lebih stabil pada $\mathrm{pH} 3$.

\section{Ucapan Terima Kasih}

Terima kasih penulis ucapkan kepada semua pihak yang telah membantu terlaksananya penelitian ini hingga selesai, terutama teman-teman dan analis pada Laboratorium Kimia Bahan Alam, Jurusan Kimia, Fakultas MIPA, Universitas Andalas Padang.

\section{Daftar Pustaka}

[1] Lydia Ninan Lestario, Hartati Soetjipto, Agustine Eviningyun, Identifikasi antosianin dan antosianidin dari daun iler (Coleus scutellariodes L. Benth) Var. Crispa dan Var. Parfivolius, Seminar Nasional Sains dan Pendidikan Sains 4, Salatiga, (2009).

[2] Ai Mahmudatussa'adah, Dedi Fardiaz, Nuri Andarwulan, Feri Kusnandar, Karakteristik Warna aan Aktivitas Antioksidan Antosianin Ubi Jalar Ungu, Jurnal Teknologi dan Industri Pangan, 25, 2, (2014) 176-184 http://dx.doi.org/10.6066/jtip.2014.25.2.176

[3] Fathinatullabibah Fathinatullabibah, Lia Umi Khasanah, Kawiji Kawiji, Stabilitas Antosianin Ekstrak Daun Jati (Tectona Grandis) terhadap Perlakuan $\mathrm{pH}$ dan Suhu, Jurnal Aplikasi Teknologi Pangan, 3, 2, (2014) 60-63

[4] Ashwini Gengatharan, Gary A. Dykes, Wee Sim Choo, Betalains: Natural plant pigments with potential application in functional foods, LWT - Food Science and Technology, 64, 2, (2015) 645-649 https://doi.org/10.1016/j.lwt.2015.06.052

[5] Kwan K. Woo, F. N. Fanny Wong, H. S. Catherine Chua, P. Y. Tang, Stability of the Spray-Dried Pigment of Red Dragon Fruit [Hylocereus polyrhizus (Weber) Britton and Rose] as a Function of Organic Acid Additives and Storage Conditions, The Philippine Agricultural Scientist, 94, 3, (2011) 264-269

[6] Y. Cai, M. Sun, H. Corke, Antioxidant activity of betalains from plants of the amaranthaceae, Journal of Agricultural and Food Chemistry, 51, 8, (2003) 22882294 http://dx.doi.org/10.1021/jf030045u

[7] Bianca Moldovan, Luminiţa David, Influence of Temperature and Preserving Agents on the Stability of Cornelian Cherries Anthocyanins, Molecules, 19, 6, (2014) 8177

[8] Puspita Sari, Christofora Hanny Wijaya, Dondin Sajuthi, Unang Supratman, Identifikasi Antosianin Buah Duwet (Syzygium cumini) Menggunakan Kromatografi Cair Kinerja Tinggi - Diode Array Detection Jurnal Teknologi dan Industri Pangan, 20, 2, (2009) 102-108

[9] Robert Byamukama, Jane Namukobe, Bernard Kiremire, Anthocyanins from leaf stalks of cassava (Manihot esculenta Crantz), African Journal of Pure and Applied Chemistry, 3, 2, (2009) 20-25

[10] Craig S. Charron, Anne C. Kurilich, Beverly A. Clevidence, Philipp W. Simon, Dawn J. Harrison, Steven J. Britz, David J. Baer, Janet A. Novotny, Bioavailability of Anthocyanins from Purple Carrot Juice: Effects of Acylation and Plant Matrix, Journal of Agricultural and Food Chemistry, 57, 4, (2009) 12261230 http://dx.doi.org/10.1021/jf802988s

[11] Ping Yang, Chunlong Yuan, Hua Wang, Fuliang Han, Yangjie Liu, Lin Wang, Yang Liu, Stability of Anthocyanins and Their Degradation Products from Cabernet Sauvignon Red Wine under Gastrointestinal $\mathrm{pH}$ and Temperature Conditions, Molecules, 23, 2, (2018) 354

[12] Raja Ramamoorthy, Natarajan Radha, Govindaraj Maheswari, Sambandam Anandan, Subbaiah Manoharan, Rayar Victor Williams, Betalain and anthocyanin dye-sensitized solar cells, Journal of Applied Electrochemistry, 46, 9, (2016) 929-941 http://dx.doi.org/10.1007/s10800-016-0974-9

[13] Tariq Pervaiz, Jiu Songtao, Faezeh Faghihi, Muhammad Salman Haider, Jinggui Fang, Naturally Occurring Anthocyanin, Structure, Functions and Biosynthetic Pathway in Fruit Plants, Journal of Plant Biochemistry \& Physiology, 5, 2, (2017) http://dx.doi.org/10.4172/2329-9029.1000187

[14] Vasil Georgiev, Mladenka Ilieva, Thomas Bley, Atanas Pavlov, Betalain production in plant in vitro systems, Acta Physiologiae Plantarum, 30, 5, (2008) 581-593 http://dx.doi.org/10.1007/s11738-0080170-6

[15] Henriette M.C. Azeredo, Betalains: properties, sources, applications, and stability - a review, International Journal of Food Science \& Technology, 44, 12, (2009) 2365-2376 http://dx.doi.org/10.1111/j.1365-2621.2007.01668.x 
[16] K.K. Woo, F.H. Ngou, L.S. Ngo, W.K. Soong, P.Y. Tang, Stability of Betalain Pigment from Red Dragon Fruit (Hylocereus polyrhizus), American Journal of Food Technology, 6, (2011) 140-148 http://dx.doi.org/10.3923/ajft.2011.140.148

[17] Simona Oancea, Olga Drăghici, pH and Thermal Stability of Anthocyanin-based Optimised Extracts of Romanian Red Onion Cultivars, Czech Journal of Food Science, 31, 3, (2013) 283-291

[18]M.Mónica Giusti, Ronald E. Wrolstad, Characterization and Measurement of Anthocyanins by UV-Visible Spectroscopy, Current Protocols in Food Analytical Chemistry, 00, 1, (2001) F1.2.1-F1.2.13 doi:10.1002/0471142913.fafo102soo 